\title{
Committee Nominates 2012-13 Officers and Council Members
}

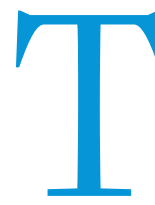

he APSA Nominating Committee is pleased to present the slate of nominees for APSA officers. In developing the slate, the committee was guided by the association's constitution that requires due regard to "geographical distribution, fields of professional interest, types of institution, race, gender, ethnicity, methodological orientation, gender identity, sexuality, and other important forms of diversity."

Many individuals and several APSA committees and groups proposed names, which aided us in our work. In particular, proposals from the status committees and organized sections are indispensable to insuring broad and diverse representation of the multiple constituencies of APSA. We thank everyone who took the time and trouble to write.

At its two-day meeting in Washington, DC, in February, the committee considered all the suggested nominations received as well as all recommendations made for APSA council or officers over the previous four years. We cast our net broadly, with particular attention to regional balance within the United States as well as representation from outside the United States. We sought to select nominees with records of excellence in scholarship, teaching, and public service as well as a broad commitment to advancing the multiple goals of the APSA. We believe we are presenting to the membership a slate of nominees each of whom is distinguished in his or her own right and who are together representative of the diverse membership of our multi-faceted association.

Committee members are Fredrick C. Harris, Columbia University; Jeffrey B. Lewis, University of California, Los Angeles; Melanie Manion, University of Wisconsin, Madison, chair; Mary L. Shanley, Vassar College; Rogers Smith, University of Pennsylvania; and Susan L. Woodward, CUNY Graduate Center.

The committee expresses its deep thanks and appreciation to Michael Brintnall and Michael Marriott of the APSA, who greatly facilitated our work and deliberations with information and support throughout the process. The nominees are noted in the following text.

\section{PRESIDENT-ELECT}

\section{John H. Aldrich}

John H. Aldrich is the Pfizer-Pratt University Professor of Political Science at Duke University. He received his BA from Allegheny College (1969; Gold Citation, 2009) and his MA (1971) and $\mathrm{PhD}$ (1975) from the University of Rochester (Distinguished Scholar Award, forth-

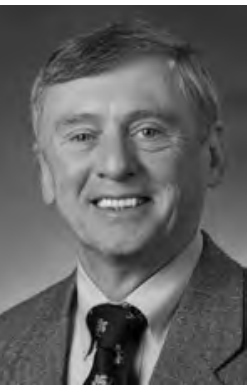
coming, 2013), in political science. At Duke he has been department chair and was the founding director and then co-director (with Prof. Wendy Wood) of Duke's Social Science Research Institute. At Duke, he also received the inaugural Graduate Mentoring Award.

Aldrich's research has been centered mostly in American politics, but more recently, his work has become more comparative. His first book, Before the Convention (University of Chicago Press, 1980) assessed presidential nomination campaigns in the postMcGovern-Fraser era of primary-centered campaigning. His book Why Parties? (University of Chicago Press, 1995; 2011) won the
Gladys Kammerer award in 1996. Since 1980, he has co-authored the Change and Continuity series on American elections (CQ Press), with Paul Abramson and David Rohde, and now being joined by Brad Gomez.

He has been actively involved in various survey research projects, including the American National Election Studies, where he currently serves as chair of its board, and is a member of the planning committee for the Comparative Study of Electoral Systems. An outgrowth of his work on the ANES is Improving Public Opinion Surveys (Princeton University Press, 2012) which he co-edited with Kathleen McGraw. Aldrich co-authored "Foreign Policy and Voting in Presidential Elections" with Eugene Borgida and John Sullivan that won the Heinz Eulau award in 1990 for best article in the APSR.

Aldrich and David Rohde have studied the relationship among political parties, elections, and the Congress. This has led to a number of articles and chapters including ones that received the CQ Press award (Legislative Studies Section, APSA) in 1966, and the Pi Sigma Alpha award (SPSA), in 1997.

Aldrich is a Fellow of the American Academy of Arts and Sciences and was a fellow at the Center for Advanced Studies in the Social and Behavioral Sciences and at the
Rockefeller Center, Bellagio. He was co-PI and then PI for a Summer Institute of Empirical Implications of Theoretical Models. He co-edited the American Journal of Political Science, chaired the APSA Task Force on Interdisciplinarity, has been a member of the APSA council and its secretary, and was president of the Southern Political Science Association and the Midwest Political Science Association.

\section{VICE PRESIDENT}

\section{Nancy J. Hirschmann}

Nancy J. Hirschmann is professor and Graduate Chair of Political Science at he University of Pennsylvania. She received her AB from Smith College and her MA and PhD from Johns Hopkins University, and was a tenured member of the Cornell University faculty before Penn. Her most recent books

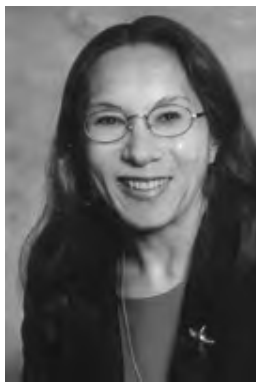
(both from Princeton University Press) are Gender, Class, and Freedom in Modern Political Theory and The Subject of Liberty: Toward a Feminist Theory of Freedom, which won the 
2004 Victoria Schuck award for the best book in Women and Politics. Her service to the profession includes the Centennial Center Advisory Board, the editorial boards of PS, Politics and Gender, and the Encyclopedia of Political Thought, the ad hoc committee to select the editors of the APSR in 2006, executive boards for several organized sections and several award committees. Her most recent research is on theoretical issues pertaining to disability.

Statement: "I am deeply honored to be nominated to serve as vice president of the association. I hope I can assist president Jane Mansbridge in whatever capacity she requires. I am concerned about diversity within the profession, both in terms of methodology and identity, and am particularly committed to efforts to increase the recruitment and visibility of women and racial minorities within the profession, as well as LGBT individuals and persons with disabilities. I am also interested in working with the APSA to increase online access at the annual meetings and digital formats for the conferences. Finally, I believe that attention to mentoring of graduate students and junior faculty, and increasing opportunities for their participation in the conferences, should be of concern to us all."

\section{Anne-Marie Slaughter}

Anne-Marie Slaughter is the Bert G.

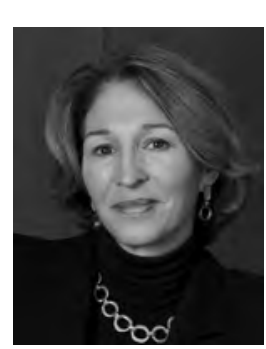
Kerstetter '66 University Professor of Politics and International Affairs at Princeton University. She received a M.Phil and D.Phil in International Relations from Oxford University and a JD from Harvard Law School. She taught at the University of Chicago Law School from 1990-94 and at Harvard Law School from 1994-2002. She served as Dean of the Woodrow Wilson School at Princeton from 2002-09 and as Director of Policy Planning in the U.S. State Department from 2009-2011, the first woman to hold both positions. While at the State Department she was the executive director of the first Quadrennial Review of Diplomacy and Development.

Slaughter began her career building bridges between international law and international relations. She also focused on the effectiveness of international tribunals, EU law and politics, legal relations among lib- eral states, and the rise of transgovernmental networks. Her book A New World Order (2004) is widely assigned on undergraduate and graduate syllabi. She has authored or co-edited five additional books and over 100 scholarly articles in legal and political science journals.

Slaughter served on the Board of Editors of the American Journal of International Law and International Organization and is a member of the American Academy of Arts and Sciences. She served as president of the American Society of International Law from 2002 to 2004 . She is an active public intellectual, writing monthly foreign policy columns for the Financial Times, Project Syndicate, and The Atlantic. She also appears regularly in the media and curates foreign policy news on Twitter.

Statement: "I am honored to be nominated for APSA vice president. I strongly support the continued engagement of political scientists with important public policy issues through publications, expert advice, and government service. US and global citizens rightly expect us to shed light not only on the deep causes of events and outcomes in domestic and international politics but also on solutions to national and global political problems. We must be able to speak to multiple audiences at once, including through blogs and social media. I also support work that combines multiple methods of equal rigor. All political scientists should be able to run statistical analyses, build formal models, and write case studies that can withstand scrutiny of the full range of available sources. The APSR should insist on careful documentation of all sources in ways that allow thorough cross-checking and informed debate."

\section{Hanes Walton, Jr.}

Hanes Walton, Jr., was born in Augusta, Georgia on September 25,1941, and educated in the public schools of Athens, Georgia, and graduated with honors in 1959. Attended and majored in political science at Morehouse College in 1963. As for graduate work,

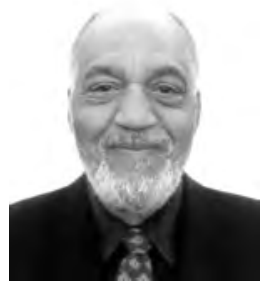
he received an MA at Atlanta University (now Clark Atlanta University) and was the first $\mathrm{PhD}$ in government at Howard University in 1967 . He is a member of Phi Beta Kappa, Pi Sigma Alpha, and received several other academic awards. $\mathrm{He}$ is a life member of APSA.
He was initially employed at Savannah State College, later at Atlanta University and currently employed at University of Michigan.

And while at State and Michigan, he has researched and published in the areas of race and politics, African politics, regulatory politics, political parties, elections, and political theory.

Out of his research, writing, and publications are books on black politics, Invisible Politics: Black Political Behavior, American Political Parties, Political Philosophy of Martin Luther King, Jr. When the Marching Stopped: The Politics of Civil Rights Regulatory Agencies, Presidential Elections, 1789-20o8, and the two volume work, The African American Electorate: A Statistical History.

Statement: "Since this is a professional academic organization, along with members of the APSA via their suggestions and input, I will search and find further ways to enrich and enhance, merit, scholarship and outstanding works and contributions to the discipline. This concern also covers pioneering and notable areas of research.

Next, along with input and suggestions from members will expand the nature and scope of professionalism both within and outside of the organization, especially in looking toward the future of the organization. Included here would be additional ways to embrace and support the newcomers to the profession as well as senior members. Finally, there is the matter of inclusion and diversity. This should be done not only in terms of membership but also in terms of the organizational structure and it programs. Such a concern will enable this professional organization to be forwardly focus both in its disciplinary teaching, membership and new professionalism.

With this kind of focus and vision, constantly supported with your suggestions and inputs during the years, I will make my term in this elective office representative of your ideas and concerns. There will be no other way to service this membership if I am given the privilege and honor to obtain the office."

\section{SECRETARY}

\section{John C. Green}

John C. Green is Distinguished Professor of Political Science and director of the Ray C. Bliss Institute of Applied Politics at the University of Akron. He is senior research advisor to the Pew Forum on Religion and Politics. He has been a collaborator on the academic outreach conferences with the American 
Association of Political Consultants. He is currently a co-director of the Ohio Civility Project.

Green is a student of American politics, with foci on religion and politics, campaign finance, and political parties. On the reli-

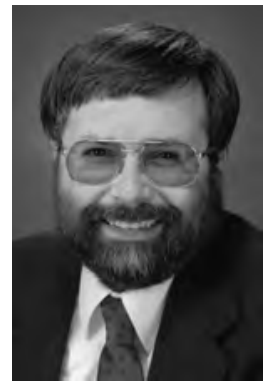
gion and politics, he is author of The Faith Factor: How Religion Influences American Elections, and co-author of The Diminishing Divide: Religion's Changing Role in American Politics and The Bully Pulpit: The Politics of Protestant Clergy. On campaign finance, he is the co-author of The Financiers ofCongressional Elections: Investors, Ideologues, and Intimates. On political parties, he is the coeditor of The State of the Parties, now in its sixth edition, and co-author of The Buckeye Battleground: Ohio Campaigns and Elections in the Twenty-first Century.

Green is widely quoted in the media on national and Ohio politics.

Green's service to the APSA includes participation in the Political Organizations and Parties section, where he has edited the section newsletter, Vox Pop, since 1989, and held a number of leadership posts. In addition, he is an active member of the Religion and Politics section. He was a member of the APSA Taskforce on Religion and Democracy in the United States.

Statement: "I look forward to working with the executive committee to strengthen the APSA. I am particularly interested in expanding public understanding of political science, both as a means to encourage greater diversity among future political scientists and as a means of improving the democratic process."

\section{COUNCIL}

\section{Gretchen Casper}

Getchen Casper is an associate professor at Penn State University. She received her BA from Boston College and her MA and PhD from the University of Michigan (Ann Arbor). She has been a visiting scholar at the University of Michigan (Ann Arbor), Peace Research Institute of Oslo (Norway),

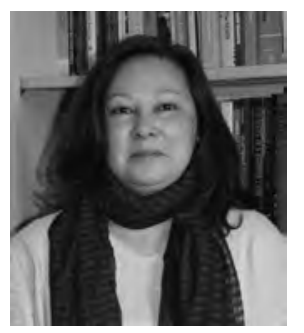
California Institute of Technology, University of Washington (Seattle), and the Institute of Philippine Culture (Manila, Philippines). Her empirical research focuses on the comparative study of democratization and utilizes a range of approaches, including large- $\mathrm{N}$, cross-regional medium- $\mathrm{N}$, and case studies. In addition, she has addressed methodological issues related to measures of democracy commonly used in large-N research. Her current work concerns how elites learn to reinforce democracy during national crises. Her work has appeared in such journals as Political Analysis, Democratization, Armed Forces and Society, and Pilipinas. Previous books include Negotiating Democracy: Transitions from Authoritarian Rule (with Michelle M. Taylor, 1996) and Fragile Democracies: Legacies of Authoritarian Rule (1995).

Statement: "It would be a privilege to serve on the APSA council. In the past, I have had the honor of serving on the Committee on the Status of Women in the Profession (2007-2010) and the Trust and Development Board (2004-2007). I have been a member of the mentoring program since 1995. In addition, I have served as an officer or as a member of various committees for three organized sections: Religion and Politics (Treasurer 1994-95), Comparative Democratization (Vice Chair 2004-06), and Comparative Politics. If elected, I would work toward 1) increasing openness, both in terms of the transparency of the association and the inclusiveness of diverse methodological approaches, 2) expanding our mentoring of women, minorities, graduate students, and junior faculty, and 3) strengthening our recognition of excellence in research and teaching."

\section{Brian F. Crisp}

Brian F. Crisp is a faculty member in the department of political science at Washington University in St. Louis. He received his $\mathrm{PhD}$ from the University of Michigan (1992) and his BA from Hope College (1985). He has also held tenure-track/ tenured positions at Wake Forest University and the University of Arizona, as well as visiting appointments

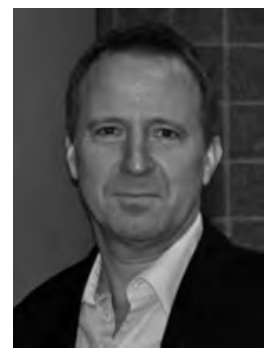
at institutions in Latin America. His work on electoral systems, legislative politics, interbranch relations, and policy choices has been published in a wide array of refereed journals, and his book, Dem- ocratic Institutional Design, was published by Stanford University Press. His research has been supported by the National Science Foundation and the Fulbright Scholars Program. He previously served as co-editor of Legislative Studies Quarterly and is currently an editorial review board member for The Journal of Politics, Electoral Studies, and Legislative Studies Quarterly.

Statement: "Both as a student and a faculty member, I have extensive experience with small, undergraduate institutions and large, research-oriented universities - as well as places that fall somewhere in between. In addition, I have been a part of both public and private universities. As a faculty member, I teach courses across the entire curriculum, from introductory, lower-division courses to graduate research seminars. If elected, I think this breadth and diversity of experiences would make me a flexible member of the council, capable of seeing many issues from a variety of perspectives. In terms of substantive concerns, issues that are priority for me include creating research experiences for undergraduates and mentoring graduates students-including how to fruitfully combining the two when possible. When issues related to these themes arise, I think I can be a particularly dynamic member of the council."

\section{Page Fortna}

Page Fortna is professor of political science at Columbia University and a member of the Saltzman Institute of War and Peace Studies. Her research focuses on the durability of peace in the aftermath of both civil and interstate wars, war termination, and terrorism. She is the author of two books:

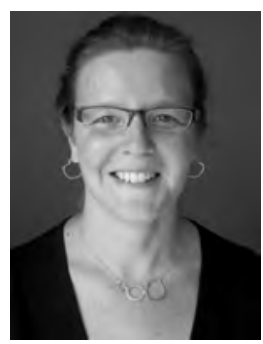
Does Peacekeeping Work? Shaping Belligerents Choices after Civil War (Princeton University Press, 2008) and Peace Time: Cease-Fire Agreements and the Durability of Peace (Princeton University Press, 2004). She has published articles in journals such as World Politics, International Organization, International Studies Quarterly, and International Studies Review. She is currently working on a book on terrorism in civil wars. Her work combines quantitative and qualitative methods, draws on diverse 
theoretical approaches, and focuses on policyrelevant questions.

Fortna received the Karl Deutsch Award from the International Studies Association in 2010. She has held fellowships at the Olin Institute at Harvard, the Center for International Security and Cooperation at Stanford, the American Academy of Arts and Sciences, and the Hoover Institution. She received her $\mathrm{PhD}$ in 1998 from Harvard University, and her BA from Wesleyan University. Within APSA, she is an at Large Executive Committee member of the Qualitative and Multi-Method Research Section, and served on the Hubert H. Humphrey Award Committee (2010 -11).

Statement: "I am committed to maintaining and enhancing the diversity of APSA, both in terms of methodology and theoretical approach, and in terms of gender, sexual orientation, minorities, and other underrepresented groups. I believe that advancing our knowledge of political processes requires drawing on multiple perspectives: across international borders; between political science and other related disciplines; across subfield boundaries within political science; across ideological lines; among scholars from different personal backgrounds; between scholars and practitioners; and especially, among scholars using different theoretical and methodological approaches and types of evidence.

If elected, I would be honored to serve on the Council, and would work to ensure that the Association:

(1) be a forum for debate and discussion that fosters cross-fertilization among increasingly specialized scholars. (2) support professional development, particularly of graduate students and scholars in early stages of their careers. (3) address the "leaky pipeline" of women and minorities in the profession. (4) promote the interests of the Political Science profession, especially by promoting understanding of the relevance and contribution of our scholarship and teaching for society as a whole."

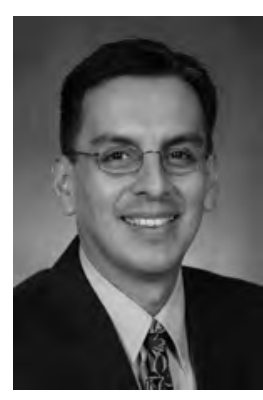

Juan Carlos Huerta

Juan Carlos Huerta is professor of political science and director of the University Core Curriculum Programs at Texas A\&M University, Corpus Christi. Huerta joined the faculty in 1995 and was appointed co-director in 2003 , and
Director in 2010. Huerta's degrees are in political science with the BA from Texas A\&M University, and MA and PhD from the University of Houston.

Huerta's political science research examines political representation and includes publications in Social Science Quarterly and the American Review of Politics. Huerta has also published in the Journal of Political Science Education and has a chapter in the APSA book Assessment in Political Science.

Dr. Huerta is deeply engaged in promoting teaching and learning in political science and served as chair of the Political Science Education Organized Section of the APSA from 2009-11. In addition, he served on the program committee for the APSA Conference on Teaching and Learning from 2006-08 and on the 2005 APSA Program Committee for the Annual Meeting.

His service to the APSA includes serving on the Political Science in the 21st Century APSA Presidential Task Force (2009-11) and the Status Committee for Latinos/Latinas in the Profession (2007-08). In addition, Huerta is active in the Southwestern Political Science Association having served as vice president and program chair (2007-08), council, and secretary-treasurer (2010-present).

Huerta leads Texas A\&M UniversityCorpus Christi's recognized First Year Learning Communities Program and is actively engaged with learning community development and first-year student success at the national level. Huerta has published research on the impact of learning communities on student learning.

Statement: "I believe the APSA is making many positive steps at becoming a more inclusive organization that more fully reflects the reality of the profession. Most of our students and faculty are at regional universities and community colleges. I want the APSA to continue the positive work at inclusiveness and outreach. If elected to the council, I will work to continue these efforts and work to engage faculty from regional universities and community colleges. I will work to promote the central role teaching and learning have in our discipline. I also want to see the APSA continue to promote programs that benefit the membership, such as the APSA Teaching and Learning Conference, and resources for assessment and effective teaching. Finally, the APSA needs to continue the efforts at recruiting and retaining faculty members from underrepresented groups."

\section{Junko Kato}

Junko Kato (PhD Yale '92) is a professor of political science at the University of Tokyo. Her research has focused on the political economy of industrial democracies, espe-

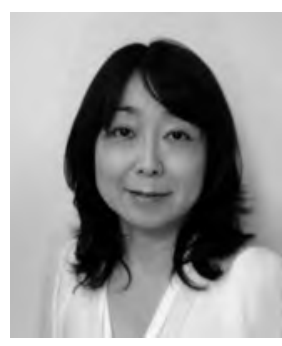
cially comparative taxation and the welfare state and empirical and theoretical studies of party coalitions. She is the author of Regressive Taxation and the Welfare State: Path Dependence and Policy Diffusion (Cambridge Studies in Comparative Politics: Cambridge University Press 2003) and The Problem of Bureaucratic Rationality: Tax Politics in Japan (Princeton University Press 1994). She has published single-authored articles in journals including American Political Science Review and British Journal of Political Science and co-authored articles in journals including Electoral Studies and Party Politics. She has held visiting positions at institutions both in the United States and Europe such as Harvard and the Stockholm School of Economics. Most recently, she has launched a neuro-cognitive analysis of political behavior and published articles in peer-reviewed, multi-disciplinary science journals, e.g., PLoS ONE and Frontiers in Behavioral Neuroscience. Kato has served as an editorial board member for British Journal of Political Science and Japanese Journal of Political Science. She served on the APSA International Committee and chaired the Mancur Olson Award Committee of the APSA Political Economy section.

Statement: "I am honored to be nominated. If elected, my efforts would be concentrated on the points specified below. First, I would like to ensure the co-existence of a variety of approaches, perspectives, and standpoints in our discipline. I began my academic career as a single country specialist and have extended my research to include cross-national comparisons using both qualitative and quantitative methods. I believe that only methodological diversity and intellectual pluralism will help us to comprehend the complexity of our political world. Although I support the effort to use multiple methods, I would emphasize the importance of in-depth research that uses or develops a single method. Second, I would like to facilitate interdisciplinary exchange and dialogue and strengthen interdisciplinary approaches in our discipline. I am excited to find that the empirical and theoretical 
knowledge that we have accumulated would be beneficial across scientific disciplines to explore human nature. Third, benefiting from my academic experience inside and outside the United States, I would like to activate APSA by furthering the diversity of our profession. I would like to guarantee opportunities for women and minorities and encourage contributions from and participation by young scholars at the early stages of their careers."

\section{Joanne M. Miller}

Joanne M. Miller is associate professor of political science and adjunct associate professor of psychology and journalism and mass communication at the University of Minnesota. She is the director of the Center for the

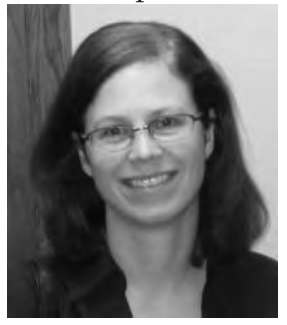
Study of Political Psychology and serves on the Governing Council of the International Society of Political Psychology. She received her PhD in Social Psychology in 2000 from the Ohio State University.

Miller is a political psychologist who studies the ways in which the media affect political attitudes and the motivations underlying a wide array of political behaviors (voting, protesting volunteering, contributing money, becoming a party delegate, and the like). Her work is explicitly interdisciplinary, drawing on theory and research in political science, mass communication, and psychology. Her work has been supported by grants from the National Science Foundation and has appeared journals such as the American Journal of Political Science, Public Opinion Quarterly, Political Psychology. She and her co-authors have received Best Paper Awards from APSA's Political Organizations and Parties organized section and the American Review of Public Administration. She has served on the conference committee for the American Association for Public Opinion Research and as a meeting division co-chair for the International Society of Political Psychology (for the section on Political Decision Making) and is an associate principal investigator for Time-Sharing Experiments for the Social Sciences.

For the APSA, Miller has served on the prize committees for the Best Political Psychology paper presented at the 2007 and 2011 Annual Meetings and for the Robert E. Lane Award for the best book in political psychology published in 2008.
Statement: "If I were fortunate to be elected to the APSA council I am committed to pursuing the following goals: 1) methodological and theoretical pluralism - encouraging pluralism in a way that is respectful to the diversity of methods that our discipline employs, 2) enhancing formal relationships between APSA and professional associations in related disciplines - such as AAPOR, ISA, etc. to further the reach of our discipline and encourage more cross-disciplinary conversation, 3) mentoring of graduate students and junior faculty - enhance these functions of APSA as both a way to increase diversity within the field and develop/professionalize young scholars."

\section{Todd C. Shaw}

Todd C. Shaw has been on the faculty of the University of South Carolina, Columbia (USC) since 2003. In August of 2012, he will hold the appointment of USC College of Arts \& Sciences Distinguished Associate Professor of Political Science \& African American Studies. He researches and teaches in the areas of African American as well as racial and ethnic politics, urban politics, public

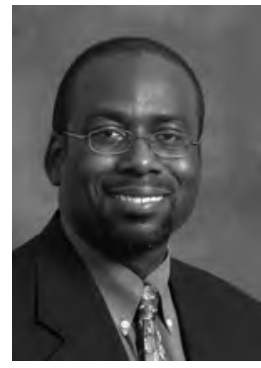
policy, and community activism. His most recent book Now Is the Time! Detroit Black Politics and Grassroots Activism (2009, Duke University Press) won the 2010 W.E.B. Du Bois Distinguished Book Award from the National Conference of Black Political Scientists (NCOBPS). Shaw's latest project is a multimethod study of Atlanta black politics as shaped by group identity, neighborhood attachments, and social capital. He has served as a member of the Executive Council of the Southern Political Science Association, as a 2012 program co-Chair for NCOBPS, and as parliamentarian of NCOBPS. He served as the director of undergraduate studies of the USC Department of Political Science from 2008 to 2011.

Statement: "Over the more than 20 years I have been an APSA member, I have observed a constructive tension. That tension is between our scholarly inquiries into questions of democratization and whether those same questions adequately animate our debates about how we govern this Association and are willing to expand the breadth of who is represented in its leadership. For the most part, I believe APSA has been quite responsive not only to demands for the increased representation of political scientists who are women, racial or ethnic minorities, lesbians and gays (among others) on the Executive Council as well as among its officers, but has expanded the scope and depth of the services and programming it provides to tackle "pipeline" problems. As a member of the council, I seek to represent my colleagues by asking APSA to think further down the pipeline. I want us to consider (for all that APSA has already done) how we might better mentor graduate and undergraduates students, better inform them of the career opportunities available in our profession, and further support departments. This is especially true as departments and their institutions pursue increased resources for graduate study, programs of undergraduate research, and opportunities for young scholars to hone their tools of inquiry and present their work at APSA and other professional conferences."

\section{Kenneth D. Wald}

Kenneth D. Wald is Distinguished Professor of Political Science and holder of the Samuel R. Shorstein Professorship in American Jewish Culture and Society at the University of Florida.

Wald studies religious and other cultural conflicts in mass political behavior. He coauthored Religion and Politics in the United States ( $6^{\text {th }}$ ed.) and The Politics of Cultural Differences, and has produced three other

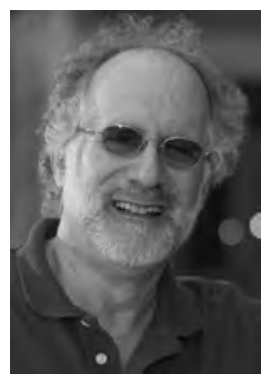
books, an edited volume, numerous journal articles and book chapters. A current or former member of the editorial boards of Politics \& Religion, American Politics Quarterly, Journal for the Scientific Study of Religion, and the Encyclopedia of Politics and Religion, he also coedits the Cambridge University Press book series, "Studies in Social Theory, Religion and Politics."

Wald has served APSA as a member of the annual meeting program committee (three terms), the Task Force on Religion and Democracy, and as chair and newsletter editor for the Organized Section on Religion and Politics. In addition he has been appointed to an NSF task force and committees of ICPSR, the American National Election Studies, the Society for the Scientific Study of Religion, the Fulbright program, 
and the British Politics Group. At the University of Florida where he has taught since 1983, Wald has chaired his department and directed an interdisciplinary center.

Statement: "I have spent much of my career studying problems that were considered marginal by many political scientists (e.g. religion in politics, conflicts over gay rights), not infrequently with unfashionable methods such as depth interviews and archival research. That experience makes me broadly sympathetic to calls for a more pluralistic discipline, pluralist both in what we study and how we study it. Achieving such pluralism is more likely if we actively promote diversity in recruiting students and faculty to the profession. I received my BA and have taught my entire career at public universities so I think it's important that APSA do what it can to help political scientists at such institutions articulate the case for the discipline and equip them to defend it (and us) from draconian cuts and vicious attacks."

\title{
Continuing Council Members
}

\author{
CONTINUING OFFICERS
}

Jane Mansbridge, incoming president 2012-2013, is the Charles F. Adams Professor at the John F. Kennedy School of Government at Harvard University. She holds an MA in history and a PhD in political science from Harvard University and a BA from Wellesley College. Her research lies at

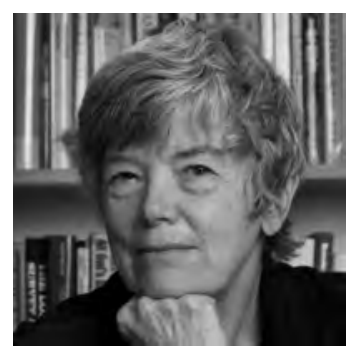

the intersection between democratic theory and empirical social science, with a focus on political in equalities and the

democratic processes that can counteract those inequalities. Her first book, Beyond Adversary Democracy, studied deliberation and inequality in two small direct democracies. Her second book, Why We Lost the ERA, co-recipient of the Kammerer award in 1987 and the Victoria Schuck Award in 1988, studied flawed deliberation within a social movement. She also edited Beyond Self-Interest, Feminism (Schools of Thought in Politics series) with Susan Moller Okin, and Oppositional Consciousness with Aldon Morris. Recent articles include "A 'Selection Model' of Political Representation," "Rethinking Representation," and "The Place of Self-Interest and the Role of Power in Democratic Deliberation" (a deliberative co-authorship with eight colleagues).

Mansbridge has been active in the Caucus for Women in Political Science, co-founded the Organization of Women Faculty at Northwestern, was a member of the Task Force on Women at Harvard, and was the founding faculty chair of the Women and Public Policy Program at the Harvard Kennedy School.
Jonathan Benjamin-Alvarado, treasurer, 2011-12, is a professor of political science at the University of Nebraska Omaha (UNO). His main areas of research are energy and trade policy in Latin America and comparative democratization. He received his $\mathrm{PhD}$ from the University of Georgia (1998). He is the author of Power to the People: Energy and the Cuban Nuclear Program (2001) and Cuba's Energy

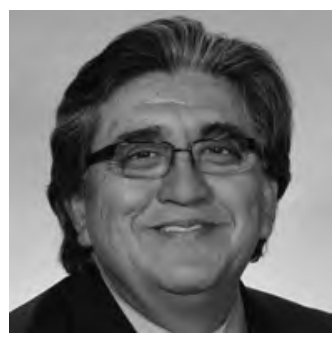

Future: Strategic Approaches to Cooperation (2010). His papers have been published in, among other places, the Political Science Quarterly, the Nonproliferation Review, and Urban Affairs Review. He is director of the Intelligence Community Scholars Program at UNO and was the founding assistant director of the Office of Latino/ Latino American Studies at UNO. He served on the APSA Council (2008-2010).

\section{COUNCIL MEMBERS 2012-2014}

Paul Gronke (PhD Michigan '93, MA Essex '84, BA Chicago '82) is a professor

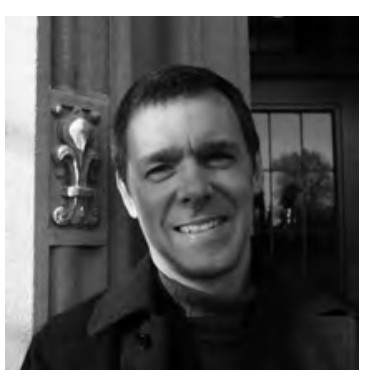
of political science at Reed College, director of the Early Voting Information Center (http://earlyvoting. net) and co-editor of the Election Law Journal. $\mathrm{He}$ has published more than two-dozen peerreviewed articles, book chapters, and a book: The Electorate, the Campaign, and The Vote (Michigan 2000). He has contributed to policy reports for the Pew Center on the States, the Election Assistance Commission, and the states of Oregon and Maryland. Gronke's academic interests include elections, election administration, public opinion, Congress, and research methods.

Gronke has served as department chair for seven years and has been on Reed's campus wide planning committee and Dean's Search committee. He sat on APSA's Trust and Development Committee, the Western Executive Council, served as communications director for the EPOVB Section of APSA, and was section head for the Southern and Western meetings.

Ange-Marie Hancock received her $\mathrm{PhD}$ in 2000 (University of North Carolins, Chapel Hill). An Irvine Dissertation Fellowship brought her to the University of San Francisco; she

later taught at Penn State and Yale before joining the University of Southern California in 2008. She is

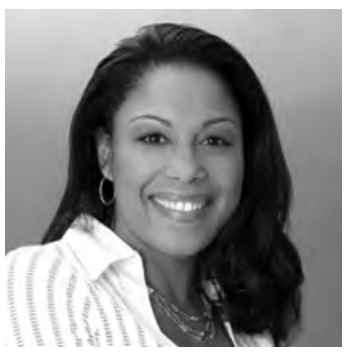
an associate professor of political science and gender studies.

Hancock is an internationally recognized scholar of intersectionality. Her first book, The Politics of Disgust and the Public Identity of the "Welfare Queen" (2004), won the W. E. B. Du Bois Best Book Award (NCOBPS) and Best First Book Award (Race, Ethnicity and Politics Section of the APSA). Her 
2007 article, "When Multiplication Doesn't Equal Quick Addition" remains the most cited article published in Perspectives on Politics. She has authored several articles and chapters; and most recently co-edited a Political Research Quarterly mini-symposium. Her newest book is Solidarity Politics for Millennials: A Guide to Ending the Oppression Olympics (2011). With Nira Yuval-Davis, she is co-editor of the Politics of Intersectionality monograph series, the first book series on intersectionality in the world.

David A. Lake is the Jerri-Ann and Gary E. Jacobs Professor of Social Sciences, Distinguished Professor of Political Science, and Acting Dean of Social Sciences (2011-2012) at the University of California, San Diego. He is the author of Hierarchy in International Relations (2009), as well as Power, Protection, and Free Trade: International Sources of U.S. Commercial Strat-

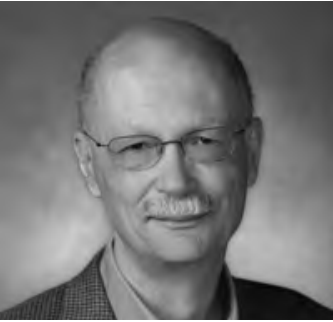
egy, 1887-1939

(1988); Entangling Relations: American Foreign Policy in its Century (1999), and World Politics: Interests, Interactions, and Institutions (2010). In addition to numerous articles and chapters, he is the co-editor of ten volumes including most recently The Credibility of Transnational NGOs: When Virtue is Not Enough (forthcoming 2012) and Politics in the New Hard Times: The Great Recession in Comparative Perspective (forthcoming). Lake has served as research director at the Institute on Global Conflict and Cooperation, co-editor of the journal International Organization, chair of UCSD's political science department, and associate dean of social sciences at UCSD. $\mathrm{He}$ is the founding chair of the International Political Economy Society, and the immediate past President of the International Studies Association. The recipient of the UCSD Chancellor's Associates Award for Excellence in Graduate Education, he was elected to the American Academy of Arts and Sciences in 2006 and was a fellow at the Center for Advanced Study in the Behavioral Sciences in 2008-2009. He received his $\mathrm{PhD}$ from Cornell University in 1984 and taught at UCLA from 1983 to 1992.
Taeku Lee is a professor and chair of political science and a professor of law at University of California, Berkeley. His primary teaching and research areas are in racial politics, public opinion, political participation,

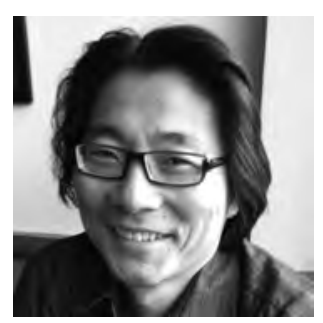
and social movements. $\mathrm{He}$ is the author of Mobilizing Public Opinion (Chicago, 2002), which received the J. David Greenstone and the V.O. Key book awards; coauthor of Why Americans Don't Join the Party (Princeton, 2011); and coauthor of Asian American Political Participation (Russell Sage, 2011). He has also co-edited Transforming Politics, Transforming America (Virginia, 2006) and Accountability through Public Opinion (World Bank 2011) and is currently co-editing the Oxford Handbook of Racial and Ethnic Politics in the United States.

Lee's prior service to the APSA includes book award committees, the Race, Ethnicity and Politics Section Executive Council, the Committee on the Status of Asian Pacific Americans, and the Task Force on Political Science in the 21st Century. Lee sits on several editorial boards (including the American Political Science Review), is on the American National Election Studies Board, and has served in advisory and consultative capacities for community-based non-profits, international organizations, think tanks, and foundations.

Kenneth J. Meier is a Distinguished Professor of Political Science and holder of the Charles $\mathrm{H}$.

Gregory Chair in Liberal Arts at Texas A\&M University, where he also directs the Project for Equity, Representation and Governance and the Carlos

H. Cantu Hispanic Education and Opportunity Endowment. He is also a professor of public management at the Cardiff University School of Business, Cardiff University (UK.).

Meier is a scholar of public administration and public policy who examines issues of equity, particularly in regard to race, ethnicity, gender, and class. His recent books include Public Management: Organizations,
Governance and Performance (Cambridge University Press, with Larry O'Toole) and The Wit and Humor of Political Science (APSA, with Lee Sigelman, Bernie Grofman, and Ken Newton). He edited the American Journal of Political Science and is currently editorin-chief of the Journal of Public Administration Research and Theory. He has served as president of the Midwest Political Science Association, the Southwest Political Science Association, and the Public Management Research Association. He is a member of the National Academy of Public Administration. His career research contributions have been recognized by the John Gaus Award from APSA and the C. Dwight Waldo Award from the American Society for Public Administration.

Kathleen Thelen is Ford Professor of Political Science at MIT. She received her BA from the University of Kansas and her $\mathrm{PhD}$ from the University of California, Berkeley. Her empirical research focuses on the political economy of the rich

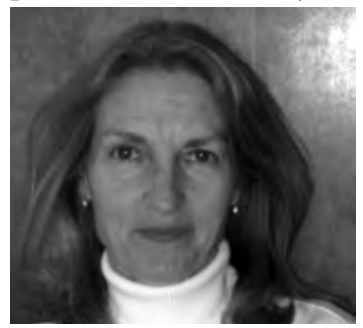
democracies, and she has also made contributions to the literature on historical institutionalism. She is the author, most recently, of How Institutions Evolve: The Political Economy of Skills in Germany, Britain, the United States and Japan (Cambridge University Press, 2004; co-winner of the APSA Woodrow Wilson Foundation Award and winner of the Mattei Dogan Award of the Society for Comparative Research) and coeditor of two volumes on institutional change, Explaining Institutional Change: Ambiguity, Agency and Power (Cambridge University Press, 2010, with James Mahoney) and Beyond Continuity: Institutional Change in Advanced Political Economies (Oxford University Press, 2005, with Wolfgang Streeck).

Thelen has strong connections abroad, particularly in Europe. She is a Permanent External Scientific Member of the Max Planck Institute for the Study of Societies (Cologne, Germany), and has also held appointments as a research fellow or visiting professor at Nuffield College (Oxford), Sciences Po (Paris), and the Copenhagen Business School. She was chair of the Council for European Studies (2002-06) and president of the Society for the Advancement of SocioEconomics (2008-09). 
Steve Walt is Robert and Renée Belfer Professor of International Affairs at Harvard's Kennedy School of Government, where he served as academic dean from 2002 to 2006. He previously taught at Princeton and the University of Chicago.

Walt's professional interests include international relations theory, security studies, and research methods. He has authored four books: The Origins of Alliances (1987), Revolution and War (1996), Taming American Power (2005), and The Israel Lobby and U.S. Foreign Policy (with John Mearsheimer, 2007). He has published over 40 scholarly articles in journals such as International Security, the American Political Science Review, and InternationalOrganization. Walt is a contributing editor at Foreign Policy, and writes a daily blog (http://walt.foreignpolicy.com).

Walt is co-editor of Cornell Studies in Security Affairs and on the editorial boards of International Relations, Security Studies, and the Journal of Cold War Studies. He serves on the Board of Governors of the Watson Institute and his APSA duties include the Ad Hoc Committee on the National Science Foundation (1999-200o) and section head for National Security Studies at the 1990 Annual Meeting. Walt is also a member of the American Academy of Arts and Sciences.

Angelia R. Wilson received her D. Phil in political philosophy from the University of York, UK and has taught at the University of Manchester for almost 20 years. Her publications include numerous articles and book chapters as well as five books in fields of political theory, comparative public policy, and sexuality politics: Below the Belt: Religion, Sexuality and the American South; Activating Theory; A Simple Matter of Justice?; Situating Intersectionality (under review) and Why
Europe is Lesbian and Gay Friendly (and Why American Never Will

$B e$ ) (under review). Wilson has been a consultant on

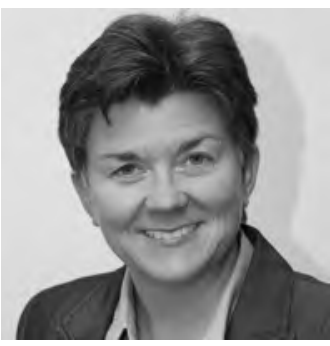
issues of gender and sexuality for the UK Equality and Human Rights Commission, the Church of England, the Children's Society, the Department of Trade \& Industry and NHS Primary Care Trusts.

Wilson has an active service record in APSA. She was one of the founders of the Sexuality and Politics Section and has chaired the LGBT Caucus. She served on the Committee on the Status of Lesbians, Gays, Bisexuals, and Transgendered in the Profession from 2006 to 2009 and is an active member of the Religion and Politics Section. As of January 2012, she will be the co-editor of Politics \& Religion. 